\title{
THE MANAGEMENT OF SELECTED YEAST STRAINS IN QUANTIFYING TERPENE FLAVOURS IN WINE
}

\author{
Ecaterina, LENGYEL ${ }^{1}$, Magda, PANAITESCU ${ }^{2}$ \\ ${ }^{1}$ „Lucian Blaga” University of Sibiu, Romania, e-mail: ecaterina.lengyel@ulbsibiu.ro \\ ${ }^{2}$ Univesidad "Latina" de Panama, Panama, Rep. de Panama, e-mail: mpanaitescu@ulatina.edu.pa
}

\begin{abstract}
This paper aims at studying the accumulation of free volatile terpene flavours (FVT) and bound precursor terpene flavours (BPT) under the action of 12 selected wine yeast strains (S1, S2, S3, S4, S5, S6, S7, S8, S9, S10, S11, S12). The importance of these flavours results from the fact that they confer wines a savoury, floral aroma; their amount is closely related to a series of factors, of which one makes the object of this analysis. The must under alcoholic fermentation comes from the Gârbova area (SebeşApold Vineyard), obtained from the variety Muscat Ottonel. The 12 strains used in the alcoholic fermentation resulted in the determination of considerable amounts of terpene flavour compounds, between $370 \mu \mathrm{g} / \mathrm{L}$ and $1100 \mu \mathrm{g} / \mathrm{L}$, which recommends their use in making quality wines.
\end{abstract}

KEY WORDS: wine yeasts, Muscat Ottonel, BPT, FVT, UV-VIS spectrophotometer

\section{INTRODUCTION}

Wine yeasts play a big part in the formation and establishment of wine sensory properties. Nowadays, great emphasis is placed on using selected yeasts of superior biotechnological properties, so as to ensure quality wines.

Human perception of wine flavours results from an entire complex of sensations conferred by various components and substances, of which some can be determined, and others not so much (Lawless and Heymann, 1998, Pacala et al.2009, Begea et al. 2009). Volatile and non-volatile compounds interacting in this process already exist or form in the grape, and depend on the processes employed in primary and secondary fermentation (Parley et al. 2001; Du Toit et al. 2006). During primary fermentation, carbohydrates in the must turn into alcohol and derivative substances, carbon dioxide and hundreds of components that contribute to the formation of wine flavour. Throughout this process, yeasts actively contribute to all the transformations, significantly improving the flavour palette of the wine (Dubourdieu et al., 2006; Tate et al., 2006; Zhang et al., 2010). Terpene compounds also play a part. Thus, linalool is a colourless liquid with a fresh floral scent reminding of spices and lemons. Under the influence of acids, linalool turns into geraniol, nerol and $\alpha$-terpineol. In grapes, linalool is accompanied by oxides. The odor detection threshold of geraniol and linalool is around four-ten times lower than that of $\alpha$-terpineol and nerol. It is easily detected, as its perception threshold is very low. Flavoured and semiflavoured varieties, especially Muscat Ottonel and Tămâioasă Românească, contain the highest concentration of linanool (Târdea, 2007; Lengyel 2014). Methyl and ethyl vanilla, providing a pleasant vanilla flavour, are characteristic of wines obtained using selected yeasts (Terrier et al. 1998; Etaino et al., 2008; Itu, 2008).

\section{MATERIALS AND METHODS}

Must made of Mucat Ottonel grapes from Gârbova, SebeșApold Vineyard, harvested in 2016, fermented using microvinification with 12 selected yeast strains, isolated in the Microbiology Laboratory from indigenous strains, coded as follows: S1, S2, S3, S4, S5, S6, S7, S8, S9, S10, S11, S12. The 12 samples underwent alcoholic fermentation under identical maceration, temperature and time conditions (12 hours, $18^{\circ} \mathrm{C}$, 15 days). We quantified free volatile terpene flavours (FVT) and bound precursor terpene flavours (BPT) from the resulting wines, using the spectrophotometric method described by Târdea, 2007, using a CECIL 1021 UV-VIS spectrophotometer . The concentration of FVT and BPT was calculated with the formula: $\operatorname{FVT} / \operatorname{BPT}(\mu \mathrm{g} / \mathrm{L})=\frac{a x b}{c x d}$, where:

$\mathrm{a}=$ concentration of linalool read on the calibration curve $(\mu \mathrm{g} / \mathrm{L})$

$\mathrm{b}=$ volume of distillate used $(\mathrm{mL})$

$\mathrm{c}=$ volume of wine used for distillation $(\mathrm{mL})$

$\mathrm{d}=$ volume of distillate used for spectrophotometric measurements.

\section{RESULTS AND DISCUSSIONS}

Wines resulting from the fermentation of must made of Muscat Ottonel grapes using the 12 yeast strains contain significant amounts of free volatile terpene flavours (FVT) and bound precursor terpene flavours (BPT). As shown in Figure 1, we recorded values between a minimum of $376.99 \mu \mathrm{g} / \mathrm{L}$ when using the strain $\mathrm{S} 11$, and a maximum of $943.97 \mu \mathrm{g} / \mathrm{L}$ free volatile terpene flavours when using the strain S6. The most valuable strains led to FVT accumulations of around $800 \mu \mathrm{g} / \mathrm{L}$. Thus, strain S1 led to an accumulation of $832.23 \mu \mathrm{g} / \mathrm{L}$, strain $\mathrm{S} 7$ to $823.44 \mu \mathrm{g} / \mathrm{L}$, and strain $\mathrm{S} 4$ to $813.87 \mu \mathrm{g} / \mathrm{L}$. Lower 27 
values were recorded when using strains S9, S10, S12, which led to amounts of $521.22 \mu \mathrm{g} / \mathrm{L}, 513.97 \mu \mathrm{g} / \mathrm{L}$, respectively $621.11 \mu \mathrm{g} / \mathrm{L}$. Important amounts of FVT were also reached when using strains S2-769.42 $\mu \mathrm{g} / \mathrm{L}, \quad \mathrm{S} 3-697.56 \mu \mathrm{g} / \mathrm{L}, \quad \mathrm{S} 8-$ $781.24 \mu \mathrm{g} / \mathrm{L}$ or $\mathrm{S} 5-756.02 \mu \mathrm{g} / \mathrm{L}$.

\section{FVT $(\mu \mathrm{g} / \mathrm{L})$}

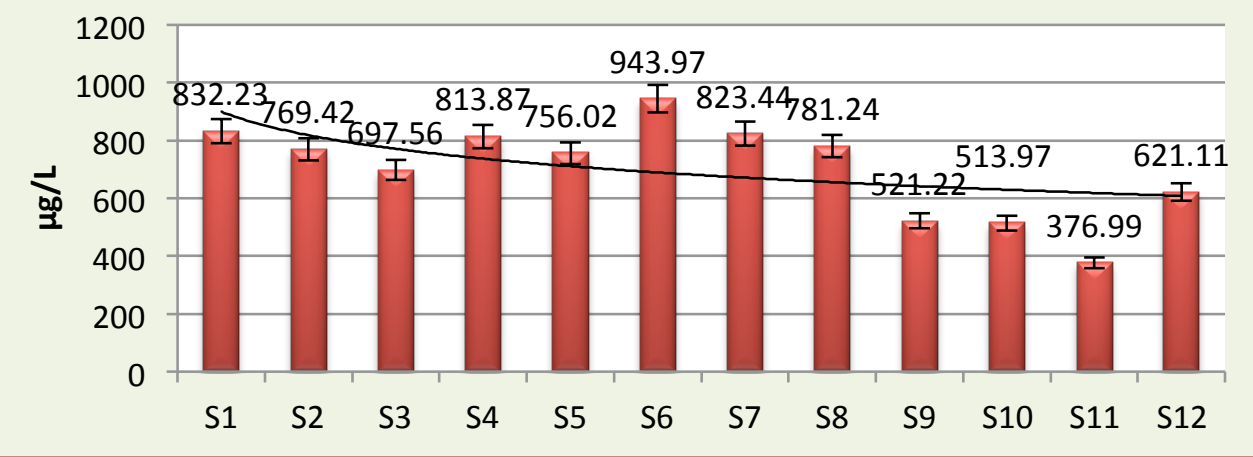

Figure 1. Evolution of the concentration of free volatile terpenic flavours (FVT) under the action of the 12 selected yeast strains (S1, S2, S3, S4, S5, S6, S7, S8, S9, S10, S11,S12)

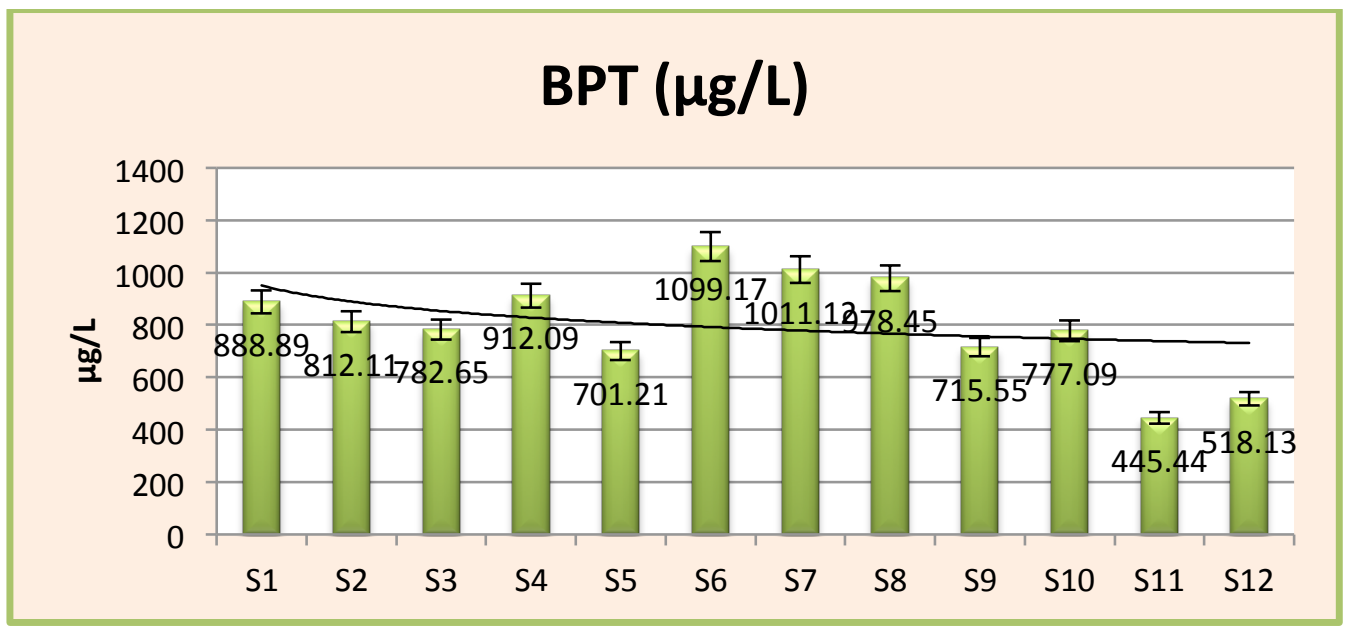

Figure 2. Evolution of the concentration bound precursor terpene flavours (BPT). under the action of the 12 selected yeast strains (S1, S2, S3, S4, S5, S6, S7, S8, S9, S10, S11,S12)

The amount of bound precursor terpene flavours (BPT) reached a minimum of $445.44 \mu \mathrm{g} / \mathrm{L}$ when using strain $\mathrm{S} 11$, and a maximum of $1099.17 \mu \mathrm{g} / \mathrm{L}$ when using strain S6 (Figure 2).

Important values were also brought about by strains S7, S8, and S4, values of bound precursor terpene flavours (BPT) reaching $1011.12 \mu \mathrm{g} / \mathrm{L}, 978.45 \mu \mathrm{g} / \mathrm{L}$, respectively $912.09 \mu \mathrm{g} / \mathrm{L}$.

\section{SUMMARY OUTPUT}

\begin{tabular}{cc}
\hline \multicolumn{2}{c}{ Regression Statistics } \\
\hline Multiple R & 0,829395 \\
R Square & 0,687897 \\
Adjusted R & \\
Square & 0,653218 \\
Standard Error & 98,33048 \\
Observations & 11 \\
\hline
\end{tabular}

Moderate values were recorded when using strains S1, S2, S3, $\mathrm{S} 9$, and S10, the amounts determined reaching $888.89 \mu \mathrm{g} / \mathrm{L}$, $812.11 \mu \mathrm{g} / \mathrm{L}, \quad 782.65 \mu \mathrm{g} / \mathrm{L}, \quad 715.55 \mu \mathrm{g} / \mathrm{L}, \quad$ respectively $777.09 \mu \mathrm{g} / \mathrm{L}$.

The results obtained were validated by the statistical model of regression Anova

\begin{tabular}{cccccc} 
ANOVA & \multicolumn{1}{c}{ Significance } \\
\hline & $d f$ & $S S$ & $M S$ & $F$ & $F$ \\
\hline Regression & 1 & 191797,8 & 191797,8 & 19,8366 & 0,001591 \\
Residual & 9 & 87019,95 & 9668,883 & & \\
Total & 10 & 278817,7 & & & \\
\hline
\end{tabular}




\begin{tabular}{|c|c|c|c|c|c|c|}
\hline \multicolumn{4}{|c|}{ Standard } & \multirow[b]{2}{*}{$P$-value } & \multirow{2}{*}{\multicolumn{2}{|c|}{$\begin{array}{c}\text { Upper } \\
95 \%\end{array}$}} \\
\hline & Coefficients & Error & $t$ Stat & & & \\
\hline Intercept & 142,5125 & 127,0216 & 1,121955 & 0,290921 & $-144,83$ & 429,8554 \\
\hline 888,89 & 0,691325 & 0,15522 & 4,45383 & 0,001591 & 0,340192 & 1,042457 \\
\hline
\end{tabular}

RESIDUAL OUTPUT

\begin{tabular}{|c|c|c|c|}
\hline Observation & $\begin{array}{c}\text { Predicted } \\
832,23\end{array}$ & Residuals & $\begin{array}{l}\text { Standard } \\
\text { Residuals }\end{array}$ \\
\hline 1 & 703,9442 & 65,47575 & 0,701893 \\
\hline 2 & 683,5778 & 13,98218 & 0,149888 \\
\hline 3 & 773,0629 & 40,80711 & 0,437448 \\
\hline 4 & 627,2763 & 128,7437 & 1,380119 \\
\hline 5 & 902,3959 & 41,57408 & 0,44567 \\
\hline 6 & 841,5248 & $-18,0848$ & $-0,19387$ \\
\hline 7 & 818,9392 & $-37,6992$ & $-0,40413$ \\
\hline 8 & 637,1899 & $-115,97$ & $-1,24319$ \\
\hline 9 & 679,7341 & $-165,764$ & $-1,77697$ \\
\hline 10 & 450,4562 & $-73,4662$ & $-0,78755$ \\
\hline 11 & 500,7086 & 120,4014 & 1,29069 \\
\hline
\end{tabular}

PROBABILITY OUTPUT

\begin{tabular}{cc}
\hline Percentile & 832,23 \\
\hline 4,545455 & 376,99 \\
13,63636 & 513,97 \\
22,72727 & 521,22 \\
31,81818 & 621,11 \\
40,90909 & 697,56 \\
50 & 756,02 \\
59,09091 & 769,42 \\
68,18182 & 781,24 \\
77,27273 & 813,87 \\
86,36364 & 823,44 \\
95,45455 & 943,97 \\
\hline
\end{tabular}

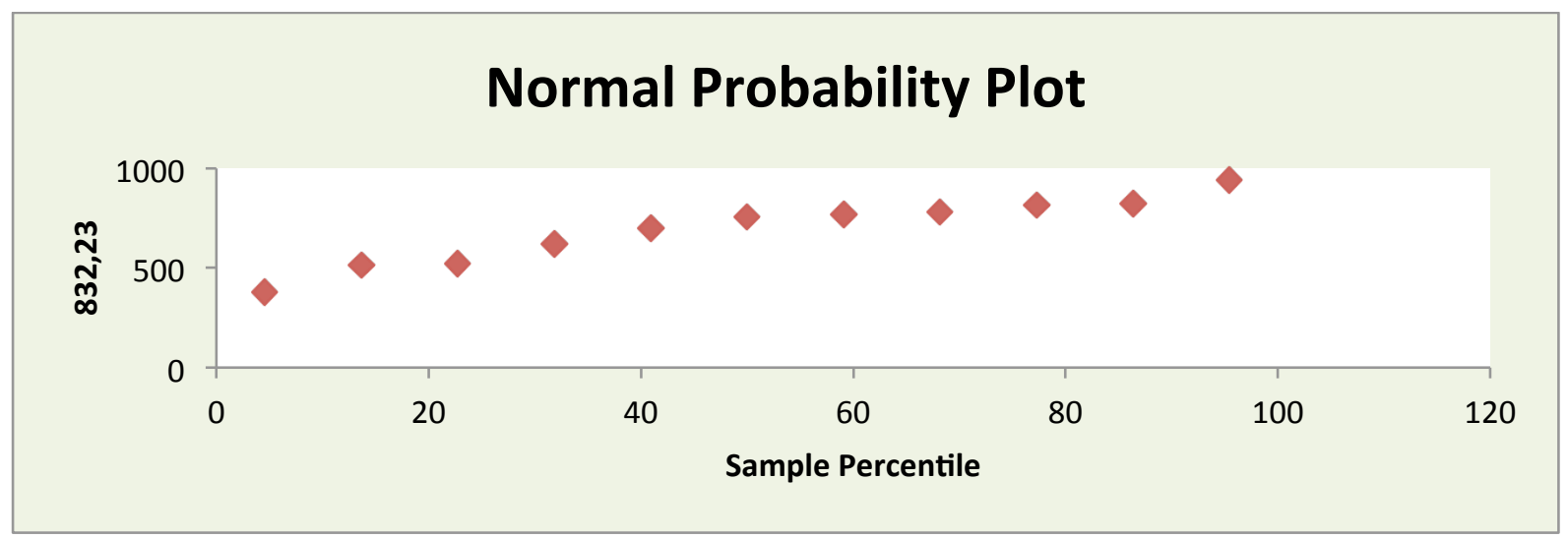

Figure 3. Regression rate of evolution of the concentration of free volatile terpenic flavours (FVT) and bound precursor terpene flavours (BPT) under the action of the 12 selected strains of yeast (S1, S2, S3, S4, S5, S6, S7, S8, S9, S10, S11, S12)

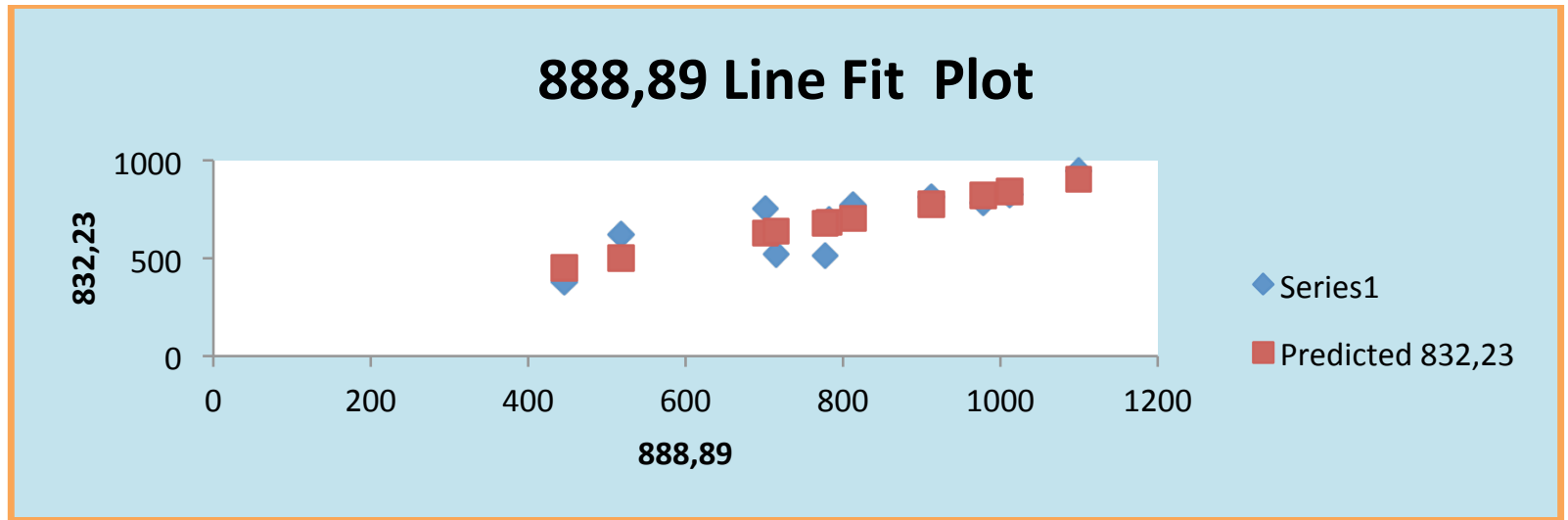

Figure 4. The prediction of the concentration of free volatile terpenic flavours (FVT) and bound precursor terpene flavours (BPT) under the action of the 12 selected strains of yeast (S1, S2, S3, S4, S5, S6, S7, S8, S9, S10, S11, S12) 
888,89 Residual Plot

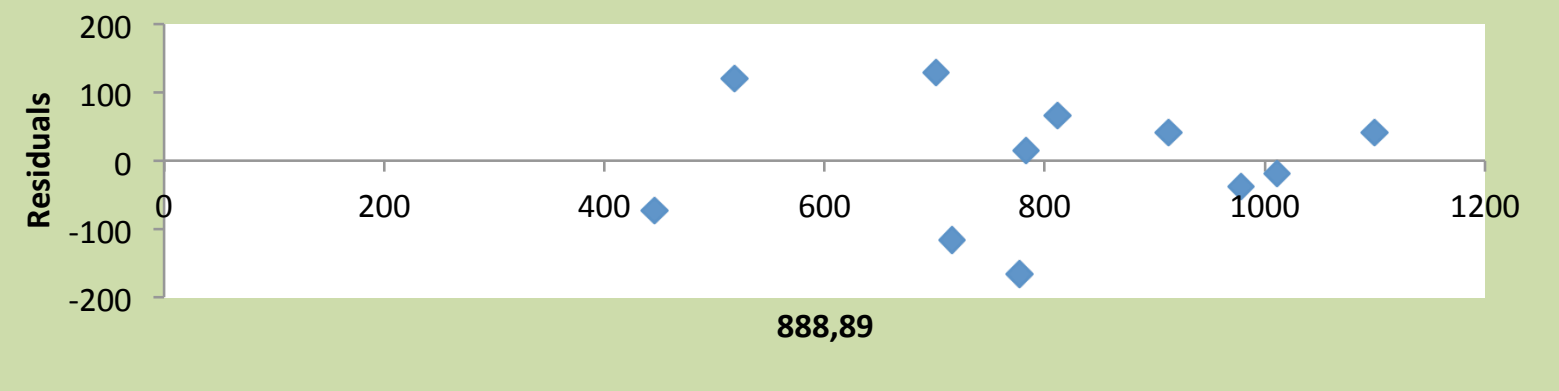

Figure 5. The residual concentration of free volatile terpenic flavours (FVT) and bound precursor terpene flavours (BPT) under the action of the 12 selected strains of yeast (S1, S2, S3, S4, S5, S6, S7, S8, S9, S10, S11, S12)

The statistical interpretation of the obtained results confirms that: Among the leaky free volatile terpene flavours (FVT) and bound precursor terpene flavours (BPT) there is a strong link. $68 \%$ of the results obtained depend on the strain of yeast used. The test $F$ is 19.8366 and the significance $F$ is 0.001591 (value less than 0.05 ), the regression model is valid and can be used to analyze the dependence between the two variables.

\section{CONCLUSIONS}

Using selected yeast strains results in a higher accumulation of terpene compounds, both free or precursor. The highest potential strains were S6, S7, and S8, followed by S1 and S4.

The lowest potential strains were S11 and S12, with values even half lower than the most valuable.

We also noticed that, out of 12 strains, only three are highly recommendable for the fermentation process, four are moderately recommendable, while the others can be used as strains whose properties can be improved through biotechnological methods.

Wine yeast contributes to the accumulation of aromatic compounds in wine, especially volatile and bound terpenes.

\section{REFERENCES}

1. Begea M., Mariana Vlădescu, Gheorghe Bâldea, Paul Begea, Cristina Stoicescu, Cornelia Câmpeanu, Alexandru Cîrîc, Mariana Liliana Păcală - Pilot technology and equipment to produce baking yeast in shorter multiplication cycle, Journal of Agroalimentary Processes and Technologies, Vol. XV, Nr. 4, Ed. Agroprint, Romania, ISSN 1453-1399, pg. 525-529

2. Du Toit, W., Marais, J., Pretorius, I.S., Du Toit, M., 2006 Oxygen in must and wine, African Journal of Enology and Viticulture, 57, 76-94

3. Dubourdie, D., Tominaga, T., Masneuf, I., Peyrot des Gachons, C., Murat, M.,L., 2006, The role of yeasts in grape flavor develpoment during fermentation: the example of Sauvignon Blanc, American Journal of Enology and Viticulture, 57, 81-88

4. Etaino, I., Elortondo, F.,J.,P., Albisu, M., Gaston, E., Ojeda, M, Schlich, P., 2008, Effect of winemaking process and addition of white grapes on the sensory and physicochemical characteristics of young red wines,
Australian Journal of Grape and Wine Research, 14, (3), 211-222

5. Itu, N., 2008, Synergy between selected yeast and $\beta$ glucosidase activity of enzymatic preparations used to obtain flavored wine, Innovative Romanian Food Biotechnology, 2, 40-47

6. Lawless, H.T. and Heymann, H. , 2010, Sensory Evaluation of Food. Principles and Practices (Springer: New York)

7. Lengyel, E., 2014, Aroma vinurilor bănățene, ed. Universității "Lucian Blaga" din Sibiu

8. Parley, A., Vanhanen, L., Heatherbel,1 D., 2001, Effects of pre-fermentation enzyme maceration on extraction and colour stability in Pinot Noir wine, Australian Journal of Grape and Wine Research, volume 7, Issue 3,146-152

9. Păcală Mariana-Liliana,, Ovidiu, Tita, Mihaela, Begea and Alexandrina, Sîrbu - HACCP study and validation by QMSFSM for brewing process-application for training of students from food technologies, Conference proceedings of $5^{\text {th }}$ Balkan Region Conference on Engineering Education \& $2^{\text {nd }}$ International Conference on Engineering and Business Education 200915 - 17 October, Lucian Blaga University of Sibiu/Romania, Vol. II, ISBN 978973-739-848-2, ISSN 1843-6730, pg. 447-452, 2009;

10. Tate David, Reynolds Andrew G., 2006, Validation of a Rapid Method for Measuring $\beta$-Glucosidase Activity in Fermenting Muscat Grape Musts Am. J. Enol. Vitic., 57,60-68

11. Terrier A., 1972- Les composes terpeniques dans l'arome des rains et de vins de certaines varietes de Vitis vinifera. These Doct., Univ., Bordeaux I.

12. Terrier N., Romieu C., 1998, Inhibition of vacuolar proton pumps by ethanol impairs berry compartmentation, Australian Journal of Grape and Wine Research, volume 4, Issue 1, 39-45

13. Țârdea, C., 2007, Chimia și analiza vinului, Ed. Ion Ionescu de la Brad

14. Zhang, H.Y., Lee, S.A., Bradbury, J.E., Warren, R.N., Sheth, H., Hooks, D.O., Richards, K.D. Gardner, R.C., 2010, Yeasts isolated from New Zealand vineyards and wineries, Australian Journal of Grape and Wine Research, Volume 16, Issue 3, 491-496 